\title{
ANTROPOCENTRISM EPIDEMIC: THE STUDY OF SOCIAL ACTION OF COMMUNITY TO THE ENVIRONMENT OF JENEBERANG RIVER
}

\author{
Hikmawaty Sabar ${ }^{*}$, Darmawan Salman ${ }^{2}$, M. Ramli AT ${ }^{3}$ \\ ${ }^{1}$ Postgraduate School, Hasanuddin University, Indonesia \\ 2 Department of Agriculture Socio-Economics, Faculty of Agriculture, Hasanuddin University, \\ Indonesia \\ ${ }^{3}$ Department of Sociology, Faculty of Social and Political Sciences, Hasanuddin University, \\ Indonesia
}

*Corresponding author E-mail: hikmasabar@gmail.com

Citation: Sabar, H., Salman, D., and Ramli, M.A.T. 2020. Antropocentrism Epidemic: The Study of Social Action of Community to the Environment of Jeneberang River. J. Asian Rur. Stud. 4(1): $37-48$

\begin{abstract}
Nowadays, the global environmental crisis is caused by fundamental philosophical errors in understanding the human way of thinking about themselves, their relation with nature, and their place in the whole ecosystem. In turn, these misconceptions lead to wrong actions. This research aims to comprehensively study the description of the anthropocentric actions of a community about the environment of the Jeneberang River. The approach used in this research is qualitative with a phenomenology method. The result of this research indicates that anthropocentric actions prioritize the desire to fulfill life's needs as if they are free to do anything with nature without considering the preservation and the balanced management of the Jeneberang River environment. There were some community anthropocentric actions found in Jeneberang River community, namely, the establishment of residence, garbage disposal, and storage of stockpiles, the establishment of the brick industry, clearing area for agricultural land, various kinds of entrepreneurial activities, and sand mining activities (have been dismissed since 2015). These actions critically impact the condition of Jeneberang River, worsening problems such as river water pollution, the silt of the river, and flash floods that happened at the beginning of 2019 .
\end{abstract}

Keywords: Antroposentrism, Social Actions, Environment, Jeneberang River

\section{Introduction}

Environmental problem is one of the global issues that surfaced in the last quartercentury, included in Indonesia so that the environmental issue becomes more interesting to be studied and discussed more deeply (Bram, 2014). Various cases of environment that raise today are sourced from human behavior (Keraf, 2006). There is a big gap between ethical judgments about the ecological crisis on one side and ethical behavior on another side (Blok, 2005).

The rapid change of ecosystem status from stable to unstable causing tremendeous ecological pressure, therefore destability of ecosystem equilibrium can be explained through the nature of the interactional relationship between humans and nature. (Dharmawan, 2007). The decrease of environmental quality and people (social) are 
mostly caused by the actions and behavior of people (Barry, 2007). Today's environmental crisis just can be overcome by changing perspective and human behavior to nature, both fundamentally and radically (Keraf, 2006). This is in line with what conveyed by Yeung that creating behavioral change of peoples is one the perquisites to find solutions to environmental problems (Tuncay et al., 2011).

The system of human and nature have a reciprocal relationship or exchanging or flowing energy, material, and information in the process of selection and adaptation (Rambo, 1981). The characteristics that explained how people influence the environmental behavior and all consequences from the influence raised, can be classified as key factors, and mainly are human factors. The human attitude that adheres to the paradigm of social dominant or frontier mentality, so that one of the causes of environmental degradation comes from human role (Putrawan, 2014). People's influence on the environment can impact three possibilities of environmental qualities, namely deterioration (decrease), keep in sustainable or improving (Daryanto, 1995). Finally, the changes in the environment will influence people (Soemarwoto, 2004).

Becker et al. (1999) stated that we focus on the relations between humans and nature in the context of ecosystem management. Identification of social factors that influence human natures needed as a base of comprehensive, normative, transparent, and operational definition of social dimension on ecosystem management (Glaser, 2006) .

Fundamental-philosophical fallacy of humans' perspective about themselves, nature, and living space in the entire ecosystem will lead to wrong actions to nature (Keraf, 2006). The fallacy in this perspective can be analyzed through deeper exploration through the mind mapping on relations between humans and nature that form a basic conceptual for various treatments in the social dimension of ecosystem management. One of the mind mappings is anthropocentrism (Glaser, 2006).

The anthropocentrism characters consider humans as the center of the universe and the only ones have value (Keraf, 2006). Nature-oriented is not laid as social actions purpose, but just as the means of humans' interest (Susilo, 2014). Marx also considered that nature has practical meaning for humans as the result of life activities and the production of life tools (Foster, 2013). Hayward interprets anthropocentrism into two. First is discussing the changes in humans' actions, and encouraging us to focus on humans. Second is promoting ethics that do not only include humans (Kopnina et al, 2018). Kortenkamp and Moore (2000), anthropocentrism assume humans as the most important in living and the other life forms are important only to the extent that they can be useful to humans. The nature of the social structure consequently not only includes humans but also other living things in general (Lawang, 2019).

The epidemic of the concept of anthropocentrism is defined as the dynamics or the process of spreading (epidemic) a certain action/character which was originally carried out by individuals then quickly moved, infecting others and spread wider. The term epidemics in this context aim to portray the massive spread and development of certain community actions into general behavior in the wider community. The community's views slowly spread like an epidemic that was quickly interpreted simultaneously by the community in various forms of daily actions towards their environment.

The Environmental Status Report (Status Lingkungan Hidup Daerah/SLHD) of South Sulawesi released in 2014 stated that the decrease in the quality of raw water resources caused by siltation, sedimentation, and contamination of surface water and soil. The siltation and sedimentation occurred due to the increase in land clearing in the 
watershed area (Daerah Aliran Sungai/DAS) and mining activities as embankment material for an urban area. Meanwhile, contamination of water surface and soil occurred due to the domestic activities, agriculture, industry, and mining .

This portrait can be found in one of the watershed areas in South Sulawesi, it is in Jeneberang River. This river flows from the middle of southern Sulawesi Island to the west coast of South Sulawesi, through Bili-Bili Reservoir and empties to the southern of Makassar. This river becomes a source of life for the community with all activities around. However, the environmental damage is not avoided due to erroneous actions that do not pay attention to the sustainability of the ecosystem around the river. The study result by WALHI South Sulawesi mentioned that Jeneberang Watershed is in a very critical condition and inadequate carrying capacity. The area is mostly non-forest areas that are transforming into an area of agriculture, rice fields, and residences area.

Responding to the facts, the tracing and classifying every action around the environment of Jeneberang River into the mind maps of anthropocentrism through a systematic series of interpretations become the stages of analysis in this research. The analysis is aimed to see the relations and interactions of humans and the environment and its relation to the environmental problems faced.

This research focuses on the causes, actions, and the impact on anthropocentrism on the overall phenomenon of environmental changes, decreased quality of life, to environmental damage that occurred in the area of the Jeneberang River. Study and analysis of those aspects aim to respond to environmental issues; especially those are related to anthropocentrism actions in environmental management. Therefore, this research is expected to contribute to shifting the various anthropocentrism actions in the Jeneberang River to the actions that prioritize more on the creation of environmental balance for the sake of ecosystem sustainability in the future.

\section{Method}

The research used a qualitative approach with a phenomenology method. The research location is in Jeneberang Watershed in the village of Parang Tambung, a subdistrict of Tamalate, Makassar City, South Sulawesi. The sampling technique uses purposive sampling; it is sampling techniques for data sources with certain considerations (Sugiyono, 2015). This purposive sampling allows researcher to collect data samples or informants by considering the scope of the data involving the wider community or large data samples. The classification is taken in order to obtain a sample of data that is representative, without having to examine it as a whole. This method is appropriate in social research such as phenomenology whose scope of data sources is large.

The total sample is 20 informants. The informant selection at first involve key informant, they are the community who live around the river, cleaning service, businessman of the brick industry, farmers, sand miner, local government, and related agencies. Further, we involved some related informants that can give deeper information for this research including Spatial Planning Department of Makassar and DAS Management Center (Balai Pengelola DAS). The data was collected by using various techniques; they were observation, interview, and documentation. Data analysis used was Miles and Huberman model that consists of data reduction, presentation, and conclusion (Sugiyono, 2015). 


\section{Result and Discussion}

\subsection{The Ecology of Jeneberang Riverbank}

The changes in land use patterns into agricultural land, fields, and settlements, and increased industrial activities will give an impact on the hydrological conditions in a watershed area (Agustiningsih et al., 2012). The environmental conditions around Jeneberang River, especially in theresearchsite (village of Parang Tambung, City of Makassar) are in worrying level. It was found significant changes which are marked by the emergence and expansion of various surrounding community's activities which are classified as ignorant behavior towards the environment (anthropocentrism). These changes are accumulated in detail through facts on the distribution areas that show the difference in conditions of the past and now.

The first, the middle area of the river is the main access to enter the Jeneberang River (accessed from Jalan Daeng Tata 3). The density occured in this area is caused by disposal activities, garbage storage and heaps, sand and stone mine storage, many entrepreneurial places, and river crossing activities. The second is the eastern area of the river became the center of all the community's activities. The condition shown the density and community's activities with their residences, entrepreneurial activities, and many more. The area along the river is filled with houses, chaotic buildings, garbage around the houses, and stacked goods. Meanwhile, there was no sanitation around the roads and houses.

The third is the western area of the river. In this area, there are three (3) disposal spots along the river embankment made by the community around (included the residence from outside the river area). The striking difference in this area is the existence of industry activities, farming, and the apprehensive river condition. Most of the river area has siltation and is overgrown by trees and grass.

\subsection{The Cause of Antropocentrism Epidemic in Jeneberang River}

To explore the cause of anthropocentrism actions which rapidly become epidemic, we can start from the review of community understanding about nature. This discussion is important because the perspective plays a role in reconstructing knowledge or values in the living of the community. All actions or attitudes of the individual and community generally come from their perspective. The urgency of perspective has the power to influence someone's action in placing themselves in other social relations. The existence of the wrong perspective on understanding nature also happens to Jeneberang River through a series of events or facts.

Thompson and Barton stated that anthropocentric belief influences the perception and actions about the environment and our relationship with it (Berenguer, 2010). And anthropocentrism takes part in putting values, perception, and worldview about the environment (Susilo, 2014). Firstly, it is caused by the perspective that assumes nature or environment is as something to use for everything. By this assumption, in 1998, the head of hamlet (Rukun Warga/RW) as the local government gave a recommendation to the community around, especially for those who difficult to have a place to live, that they could stay around the empty area of the Jeneberang River which has many trees. Eventually, the people began to stay and build houses around the river based on this recommendation. 
Secondly, people came and stayed around the river area. In 1998, there were only 10 houses with a far distance each other. However, in 2008, the total of the houses increased to 50 houses. In 2018, It becomes 300 houses (excluded other hamlet with hundreds of houses). The houses are no longer distant and the condition becomes congested and tight. This density keeps increasing because the community gives information, call, invite, and encourage each other to live there.Thirdly, regulation and supervision are weak. The role of a certain person also becomes the cause of the density of the river. Since the people stayed in the river area in 1998, the related regulation to the prohibition was just confirmed through Local Regulation regarding Spatial Planning Area (Rencana Tata Ruang Wilayah/RTRW) of Makassar City in 2015. Even though the other regulation also rules river basin management, but it does not give effect to reduce the enthusiasm for people to live around the river.

\subsection{The Condition before the Epidemic}

The environmental condition of Jeneberang River and around were very differenybefore and after the people stayed around the river area. At first, the river area was narrowbut the river ground lands around, included lands owned by the community around and made the river wider. Besides that, the river area was also fulfilled by various trees and empty lands spread along the downstream. Nowadays, the downstream of the Jeneberang River have been filled by houses and many entrepreneurial places. The houses are not neatly arranged. The condition is chaotic and crowded. Many houses are in poor condition. Disposal dan garbage collection activities, the existence of the brick industry, farming land clearing, are some activities worsen and increasing crowding around the river area. The comparison of past and recent condition of the river clearly shows that there is a significant change which tends to lead to the adverse effect on the existence and sustainability of ecosystem around the river.

\subsection{The Forms of Community Anthropocentrism Actions}

The Forms of Community Anthropocentrism Actions. Increasing of development in the sector of settlement, agriculture, plantation, industry, and natural resources extraction in the form of mining and forest exploitation cause the decrease of the horological condition in the watershed area (Efendi, 2008). Here some community actions to the environment around Jeneberang River which are categorized as anthropocentrism.

\subsubsection{Establishment of Residence}

The increasing of population and living in riverbanks will influence someone's behavior (Heimstra and McFarling, 1974). The existence of residences along the river area becomes one of the most prominent activities from others. The dense settlement raises other activities, like disposal spots, farming area, industry, and entrepreneurial places that are increasing the environmental burden. The year of 1998 becomes the period of the entrance to the people to come and settle their houses. At first there were only a few houses, however, it increases every year unstoppable. Today, the accumulation from more than 20 years, the number of houses has become hundreds ( \pm 300 houses), not included other entrepreneurial buildings. This enhancement impacts upon the amount of domestic waste disposal that affects the river water quality (Puspita et al, 2016). The change of condition around the river a place to live and believed as 
utilization for any purpose ha/had given a significant impact on the decrease of the river ecosystem.

\subsubsection{Laystall/Rubbish Shelters and Heaps}

The year 2016 was the beginning of the garbage containers entry. Previously, the garbage containers were put in the axis roads or in each urban village. However, the regulation of Makassar Mayor rules waste management, banned the placement of garbage containers in the city. So they were moved to the strategic location to be rubbish shelters. The area selection of the river as the garbage containers spot is determined based on the consideration of the area around the river that is quite extensive and strategic, so it can be used for waste activities. Beside domestic waste, there are many used piles out of the river area. The increasing heaps cause the river area is taken. The garbage is also piled up around the community's houses. Besides that, the garbage disposal spots are also spread in river embankment. The people that live outside the river seem free to dispose of their garbage, whereas their house distance between/from the rubbish shelter is quite near. These conditions make the river area polluted and dirty.

\subsubsection{Clearing Area for Farming}

Along the area of Jeneberang River in Parang Tambung, there are two (2) locations of community farmland. The first location is nearer to the center of community activities. The second is located on dry river land. The difference, the first location has been used for 10 years, while the second one is just started at the beginning of 2019 and it is not harvested yet because the land was attacked by flash floods. The farmland is quite wide and grown various kinds of seasonal plants, namely vegetables and fruits. In watershed management rules, there is land conservation where farmland is not recommended because it can impact land degradation, and also the use of plant fertilizer will affect soil pollution and it is directly connected to the water sources of the river. The pattern of seasonal farm activities is not allowed in land utilization around the river.

\subsubsection{Establishment of Brick Industry}

Before the brick industry was operated around Jeneberang River, it is located in front of axis road, however, because of the noise resulted from the machines when operated and ruined the people around, the factory finally was moved nearby the river. The displacement did because the area was not utilized and only fulfilled by garbage. This activity has been going on for a long time, it is around 10 years. Seeing nature as something can be utilized still becomes a common reason as a basis to respond to the change happened. The term utilization of nature due to the opportunity to use the river space for any purpose has changed the businessmen's mind to relocate their factory to the strategic area, nearby the river.

\subsubsection{Establishment of Entrepreneurial Places}

Urban communities that live near rivers will cause land movements such as erosion and landslides (Goransson et al., 2015). The existence of various kinds of entrepreneurship can be found in some spots, like in the middle and at the corner of the residential area and in the edge of the river. The business activities are aluminum, 
furniture, workshops, plastic waste warehouses, selling sand and stone, Tempe, and the number of food stalls.

The widespread of the entrepreneurship is caused by the easy access that can be obtained for those who want to use the area around the river. It is just by paying the cost of renting land around the river, both the land owned by an individual based on the ownership rights, or exemption land or state-owned.

Waste of entrepreneurial activities is increasing and polluting the environment of the river. The entrepreneurial activities will finally reinforce the humans' domination to nature which can be freely done for the sake of the fulfillment of life needs.

\subsubsection{Sand Mining}

The mining activities along the river course caused the waste to block the water and worsen the drying condition (Meisanti et al.,2012). The activities have been the main factor of the siltation in Jeneberang River. Digging, dredging, and sand extraction in the river area has brought a bad impact to the river environment today. Even though the mining activities have stopped for 5 years ago, starting from 2015, but the impact caused is still seen until now. When sand mining was still active, the miners massively exploited the river by operating boats to take the excavated sand from the mine workers. The boats for mining activities are almost alongside the river. Every day, they excavated the river to take sand that will be traded as constructions materials.

The existence of sand mining has been a big scourge for the damage of the river environment. The activities are massively done from upstream to downstream across some districts/cities. Even though some permits have been revoked in some areas, but in others, like in Bili-bili, Gowa District, the activities are still going on until now.

\subsection{The Impact of Antropocentrism Actions}

\subsubsection{Water Pollution}

The water quality of Jeneberang River as one of the main sources of drinking water for Makassar and its surrounding is quite alarming. According to the data from the Regional Environmental Agency of South Sulawesi at the last 2013, the water quality of Jeneberang was in the severe level of pollutants. Generally, water pollution is from erosion on the edge of the river caused by deforestation. The pollution is also caused by mining activities in the river bank. This causes the increasing of sedimentation in the river flow.

Another problem faced is community activities around the river that causing river pollution, like farming, domestic waste, hotel, tourism area, people who throw garbage into the river, and also the excessive use of soil fertilizer.

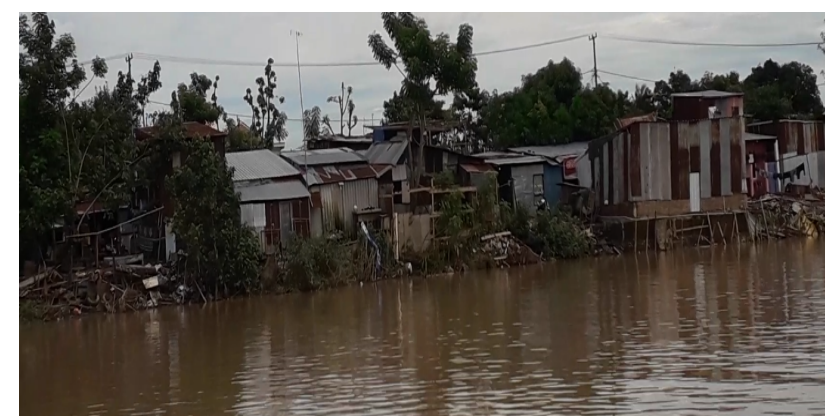

Figure 1. The water quality of Jeneberang River 


\subsubsection{River Siltation}

Human activities that change the landscape will continually affect sediment in the river (Restrepo danKettner, 2012). The siltation of Jeneberang River is at an alarming level. In some latest years, Jeneberang has experienced land degradation as the effect of the community's activities patterns which chaos exploit the river area. One of the activities causing siltation is sand mining. This activity digs and takes sand from the river both manually and using a machine. The massive sand mining has taken place in the past few decades, now the river experiences drastic shrinkage.

The siltation also gives effect to the river water quality where the color has changed into dark brown due to the mud. In the river area with water, the depth is lower even almost dry if the dry season comes for a long time. Indeed, in some parts of the river that are drying up, trees and bushes are growing.

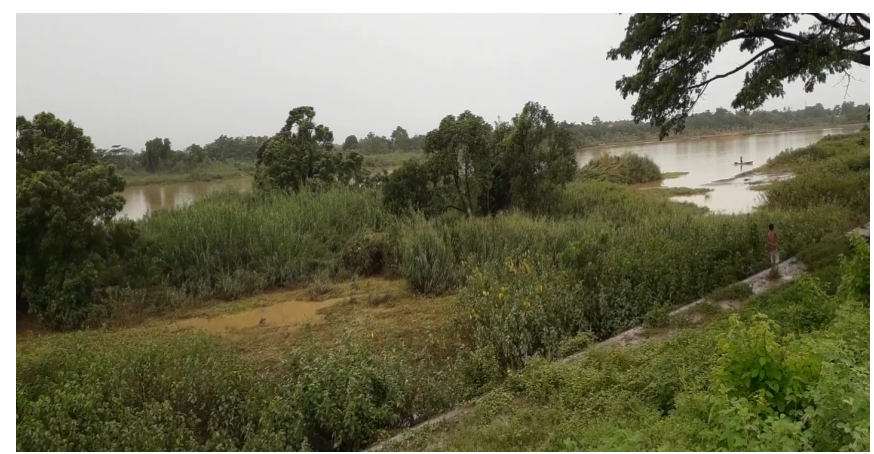

Figure 2. The siltation of Jeneberang River

\subsubsection{Flash Floods}

This incident happened in January 2019. This was the first flash flood in Jeneberang River. In the last three decades, this river has never experienced a flash flood. Previously, even the rain fell with high intensity; the water just swamped houses and roads around the river, especially in the area of Parang Tambung. The incident of flash flood happened, not only caused by the big number of water from Bili-bili, but the condition around the river was critical so it cannot be water absorption area due to the siltation.

The activities of the local community also contribute to the degradation of the ecosystem in Jeneberang River. Dense settlement, sand mining activities before, the establishment of industry, horticulture farmland clearing, entrepreneurial activities, and waste disposal and heaps become a set of domination by people around to the environment of Jeneberang River. 


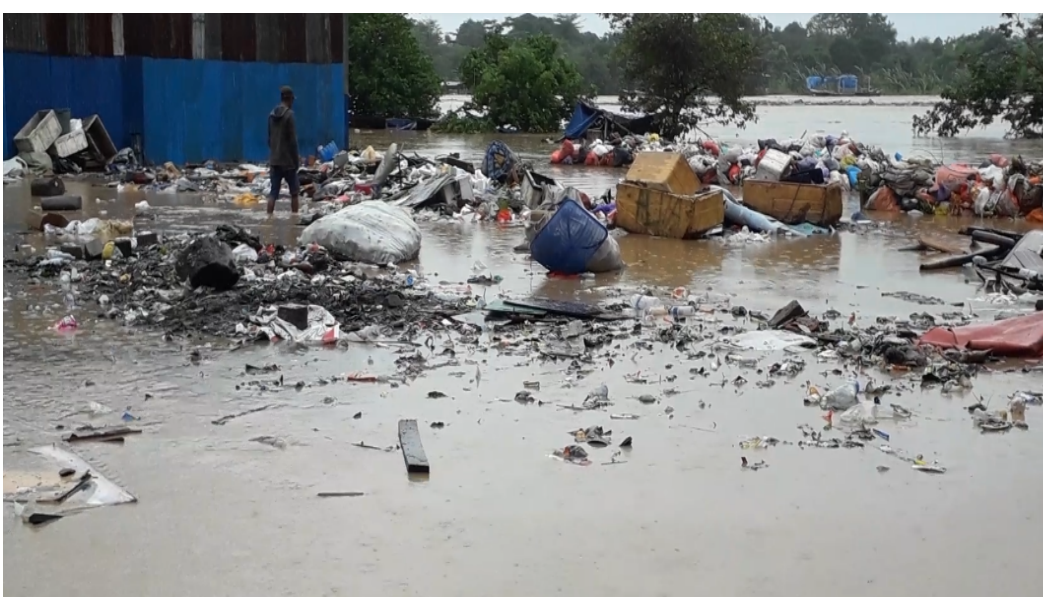

Figure 3. First flash flood in Jeneberang River

\subsection{Type of the Ongoing Antropocentrism and its Level of Impact}

\subsubsection{Type of the Ongoing Antropocentrism Related to the Theory}

The community anthropocentrism actions to the environment of Jeneberang River is included in the type of moderate anthropocentric (nature for humanity) which consider nature only in its function to fulfill all the life needs of the humans. The manifestation of natural existence on the land condition around the river has made people can use it freely for their life needs and they keep assumpted their actions as the form of utilization.

Analysis of community social action in relation to a mind map is also in line with social actions theory from some experts, like Blumer with his symbolic interactionism theory and Weber with his social action theory. In symbolic interactionism theory, human actions are interpreted as the result of a series of interpretation and its choices in a certain social setting (Wirawan, 2012). This theory is suitable with the meaning of Moderat Anthropocentric (nature for humanity) mind map. The actions of humans come from the interpretation or viewpoint in the environment where they live.

The perspective of Moderat Anthropocentric which considers nature only in its function to fulfill the community life needs then is manifested by making an alternative in form of desire to utilize the land around the river through the roles they played as the part of respond or stimulus to the surrounding environment. Weber's social action theory is oriented to the motives and goals of the actors. By using this theory, we can understand the attitude of individual or group that each has different motives and goals to an action they do (Muhlis dan Nurkholis, 2016). The community actions to the environment of Jeneberang River commonly have the same goal, it is to utilize nature for their daily needs. The actions can be building houses, industry, sand mining, and so on. Their motives are started from their idea of moderate anthropocentric then they state it as the basis to reach their goals.

\subsubsection{Analysis of the Relation of the Ongoing Antropocentrism Type with Its Impact}

The nature for humanity or moderate anthropocentric idea of community to the environment of Jeneberang gives real impact to the ecosystem change that gradually begins to show alarming condition. Slowly, various negligent actions of the community have changed the nature condition that used to be healthy and free from damage, now 
drastically experiences the reduction of environment quality. It can be seen from the pollution of river water due to various wastes, land degradation as the effect of land conservation which ignore the area of downstream, the emerging of station in some river part due to the massive sand mining, until the flash flood due to the damage of upstream to downstream, where the river cannot absorb the rainwater because of siltation and mud.

Various impacts present are the accumulation from each anthropocentrism actions of people that since long ago consider the existence of the environment surrounding the river as something that just can be utilized for any purpose. The environmental damage is also considered that whatever happens to the environment, the efforts to recover, to maintain, and process it sustainably is just theory without any realization.

\section{Conclusion}

Community's wrong perspective in considering the existence of nature can be found in the environment of Jeneberang River. The mistake is manifested through free and negligent actions to the river environment. The forms of community's anthropocentrism actions to the environment of Jeneberang River are the establishment of shelters, disposal and storage garbage and heaps, the establishment of the brick industry, farmland clearing, various entrepreneurial activities, and sand mining (it has been stopped since 2015). The actions have impacted the environment of Jeneberang River which is increasingly critical with some conditions, like river water pollution, river siltation, and flash flood at the beginning of 2019.

\section{References}

Agustiningsih, Dyah., Sasongko, S.B., Sudarno. 2012. Analisis Kualitas Air dan Strategi Pengendalian Pencemaran Air Sungai Blukar Kabupaten Kendal, Jurnal Presipitasi, 9 (2):64.

Barry, J. 2007. Environment and Social Theory. London: Routledge.

Berenguer, Jaime. 2010. The Effect of Empathy in Environmental Moral Reasoning. Journal Environment and Behavior, 42(1):113.

Blok, Vincent. 2015. The Human Glance, the Experience of Environmental Distress and the "Affordance" of Nature: Toward a Phenomenology of the Ecological Crisis. Journal Agricultural Environmental Ethics, 28: 926.

Bram, Deni. 2014. PolitikHukumPengelolaanLingkungan. Malang: Setara Press.

Burchett, L, Kyle. 2016. Antropocentrism as Environmental Ethic. Dissertations Philosophy, University of Kentucky.

Daryanto. 1995. Masalah Pencemaran. Bandung: Tarsito.

Dharmawan, A. H. 2007. Dinamika Sosio-Ekologi Pedesaan: Perspektif dan Pertautan Keilmuan Ekologi Manusia, Sosiologi Lingkungan dan Ekologi Politik. Sodality, Jurnal Transdisiplin Sosiologi, Komunikasi, dan Ekologi Manusia, 1(1): 09.

Efendi, Edi. 2008. Kajian Model Pengelolaan Daerah Aliran Sungai (Das) Terpadu. Direktorat Kehutanan dan Konservasi Sumberdaya Air, Badan Perencanaan Pembangunan Nasional (Bappenas). 
Foster, Bellamy J. 2013. Ekologi Marx Materialisme dan Alam (EdisiTerjemahan). Jakarta: Wahana Lingkungan Hidup Indonesia (WALHI).

Glaser, Marion. 2006. The Social Dimension in Ecosystem Management: Strengths and Weaknesses of Human-Nature Mind Maps. Journal Human Ecology Review, 13(2):122.

Goransson, G., Norman, J., Larson, M., Alen, C., Lars-Rosen, L., 2015. A Methodology for Estimating Risks Associated With Landslides of Contaminated Soil Into Rivers, Jurnal Science of the Total Environment,472: 481.

Heimstra, N.W., and McFarling, L. 1974. Environmental Psychology. California: Wadsworth.

Keraf, Sony. 2006. Etika Lingkungan. Jakarta: PenerbitBukuKompas.

Kopnina, Helen., W.H., Taylor, Bron.,Piccolo, J.J. 2018. Anthropocentrism: More than Just a Misunderstood Problem, Journal Agricultural Enviromental Ethics, 31:114.

Kortenkamp, K.V and Moore, Collen. 2000. Ecocentrism and Anthropocentrism: Moral Reasoning about Ecological Commons Dilemmas. Journal of Environmental Psychology, 6(06):02.

Lawang, Robert M.Z. 2019. Small Farmers and Conversion: The Role of Social Capital (Evidence From Manggarai, Flores, East Nusa tenggara, Indonesia), Journal of Asian Rural Studies, 3(1): 50.

Meisanti., Ali, M. Saleh. S., Jusoff, Kamaruzaman., Salman, Darmawan., Rukmana, Didi. 2012. The Impacts of Gold Mining on the Farmer's Community, American-Eurasian Journal of Sustainable Agriculture, 6(4): 211.

Muhlis, Alis and Nurkholis. 2016. Analisis Tindakan Sosial Max Weber dalam Tradisi Pembacaan Kitab Mukhtashar Al-Bukhari (Studi Living Hadis), Jurnal Living Hadis, 1(2): 248.

Puspita, Ira., Ibrahim, Linda., Hartono, Djoko. 2016. Pengaruh Perilaku Masyarakat yang Bermukim di Kawasan Bantaran Sungai Terhadap Penurunan Kualitas Air Sungai Karang Anyar Kota Tarakan, Jurnal Manusia dan Lingkungan, 23 (2): 252.

Putrawan, I Made. 2014. Konsep-konsep Dasar Ekologi Dalam Bebagai Aktivitas Lingkungan. Bandung: Alfabeta.

Rambo, A, Terry. 1981. Conceptual Approaches to Human Ecology: A Sourcebook On Alternative for the Study of Human Interactions with the Environment. Hawaii: East-West Environment and Policy Institute Honululu.

Restrepo, J.D., \& Kettner, A., 2012. Human Induced Discharge Diversion in A Tropical Delta and Its Environmental Implication: The Patia River, Colombia, Journal of Hydrology. 424-425:124

Soemarwoto, Otto. 2004. Ekologi, Lingkungan Hidup, dan Pembangunan (cetakan kesepuluh). Jakarta : Djambatan.

Sugiyono. 2015. Metode Penelitian dan Pengembangan. Bandung: Alfabeta.

Susilo, R.K. (ed.4) 2014. Sosiologi Lingkungan. Jakarta: Rajawali Press.

Tuncay, Busra., Tuzun, O.Y., and Teksoz, G.T. 2011. The Relationship Between Environmental Moral Reasoning and Environmental Attitudes of Pre-Service Science Teachers, International Electronic Journal of Environmental Education, 1(3): 168. 
Wahana Lingkungan Hidup (WALHI) Sulawesi Selatan. DAS Jeneberang Kritis, Keselamatan Warga Terancam. Available Access (online) http:www.walhi.or.id, 07 Februari 2019.

Wirawan, I, B. (ed.1) 2012. Teori-teori Sosial Dalam Tiga Paradigma; Fakta Sosial, Paradigma Sosial, dan Perilaku Sosial. Jakarta: Prenadamedia Group. 